\title{
Egalitarian Society Through the Value of Tat Twam Asi, a Review of Local Wisdom
}

\author{
Muhammad Abror $\mathrm{A}^{1}$ Nunuk Suryani ${ }^{2}$ Deny Tri Ardianto ${ }^{3}$ \\ ${ }^{1,2,3}$ Sebelas Maret University \\ 1abror.m@student.uns.ac.id, ${ }^{2}$ nunuksuryani@staff.uns.ac.id, ${ }^{3}$ denytri@staff.uns.ac.id
}

\begin{abstract}
Tat Twam Asi values convey the values of equality, tolerance, social solidarity, social empathy, and others, thus if they are truly applied in the social life of the community, they will produce a harmonious society and a conducive social condition (social cohesion). The purpose of this research is our efforts to apply the values of Tat Twam Asi about equality, tolerance, social solidarity can be applied in everyday life so as to lead to a harmonious society and social system. The research method used in this study was a constructivist grounded theory with an interpretive approach in qualitative research, with flexible guidelines, focusing on developed theories that depend on researchers' views, while at the same time giving greater emphasis in terms of values, views, beliefs, assumptions, and ideologies. This theory also supports a social constructivist perspective that includes an emphasis on a variety of local worlds, diverse realities, and complexities of particular worlds, views, and actions. Thereby, the high moral value of Tat Twam Asi should be the focus of public attention in social behavior and social interaction. Thus, the harmonious social ideals of society are not just empty ideals in the midst of an atmosphere of social life that is prone to friction between community groups and the individual community itself. So that the realization of a more egalitarian (civil society) society would be realized by the application and application of the Tat Twam $A s i$ values in a serious, sustainable and consistent manner.
\end{abstract}

Keywords: Tat Twam Asi, Local Wisdom, Egalitarian Society

\section{Introduction}

Social issues regarding equality and justice in society today, have become a topic that is often discussed. These problems are related to the issue of declining relationships in terms of socio-cultural, religious, racial, ethnic and ethnic groups and others. This indicates that the values contained in the local traditions of the community itself are gradually being left behind or even forgotten by the local community. Globalization, as well as westernization that occurs in terms of socio-culture which has become a large current in society, is one of the reasons for the increasingly local values and traditions abandonment of the local community. The former Indonesian people who were famous for their brotherhood, kinship, and friendliness, now have turned into a society that could be said to be indifferent to their values, norms and social ethics in social relations with the surrounding community. The public seems to forget about the 
historical roots of its past civilization which is so grand with its value system and social norms which were inherited from the previous ancestors. Samuel Huntington stated that the future of the world would increasingly lead to clashes between cultures and even between civilizations [1].

As an example of the case, the recent issue of Presidential Election 2019 lively occurred in the world of (the Internet), as well as in social conditions. This was conveyed directly by LIPI (Indonesian Institute of Sciences) that identity, ethnicity, race and intergroup politics (SARA) were being the highest factors predicted to hamper the late coming election, the low level of which needed to be examined with this issue [2]. The survey from LIPI (Indonesian Institute of Sciences) actually came true in the 2019 election event that was being fulled of SARA issues that occurred in the midst of society. Social conflicts that occurred in various regions in Kalimantan, Maluku, Papua, Aceh, and several others, if sorted out easily they could be divided into two categories. First, social conflict with a background of separatism. The second, conflict related to SARA issues. The findings of the United Nations Support Facility for Indonesian Recovery (UNSFIR), an institution under the auspices of the United Nations Development Program (UNDP) showed the number of social conflicts in Indonesia from 1990 to 2003 amounted to 10,758 people, while being followed up according to the number of cases as many as 3,608 cases. This shows the fact that social conflict caused victims as well as threatening social harmony and social integration in society [3].

Universal values in the discourse of humanity must be a dialogue with the treasures of local wisdom, global vision must be integrated with the digestibility of local culture, in this dialogical struggle developed through the path of internalization and externalization [4]. Local wisdom is dynamic functional the local wisdom that is connected to the global situation, local wisdom is the human intelligence in one ethnic community obtained through their life experience, the form of local wisdom is commonly into the idea, social activity, and artifact [5]. Local wisdom often called local genius can be understood as a human effort using his intelligence (cognition) to act and behave towards things, objects, or even that occur in a given place, this definition is arranged in etymology, in which wisdom is understood as the ability of a person in using reasonable mind to act or to behave as a result of an assessment of things, objects, or events that occur. [6]

Local wisdom [7], is a view of life and a set of knowledge and various life strategies in the form of activities carried out by local communities in answering various problems in the fulfillment of their lives. Local wisdom contained in the community can take the form of values, norms, customs, and knowledge as a guide to life continues to be preserved, local knowledge has ethical and moral significance with regard to the existence of nature and its content [8]. Local wisdom is [9], an entity that vocally determines human dignity. This means that local wisdom is a view of life and a set of knowledge useful for human civilization to form a social harmony and social integration with the values that exist in local wisdom.

The idea of the doctrine of equality is dug from social values such as Tat Twam Asi. Moral teaching that recognizes equality and equality in human life. This teaching is included in the teaching of unlimited morality which is a philosophy of Hinduism. This teaching is in accordance with the Second Precepts of Pancasila which recognizes the human status as a creature that has the same value as other humans and has the same rights and obligations towards other humans [10]. The pattern of the harmonious relationship among humans is stated in the concept of Tat Twam Asi which means "you are me and I am you", this concept contains the meaning of love and solidarity in having a harmonious relationship among humans [11] 
The notion of equality extracted from the values of local wisdom becomes the basis of community social behavior and life to realize social cohesion among the people. Social cohesion [12], the creation of a society where people have the opportunity to jointly discuss with all differences and other sides, ways to achieve unity and diversity. The composition of the structure and the atmosphere of social harmony and social cohesion in the community environment encourage and create naturally and substantially egalitarian societies in all fields of life or commonly referred to as civil society in the idea of Indonesia as a nation. Substantially, civil society is almost as understanding as a society that is egalitarian. Civil society implies tolerance, the willingness of individuals to accept various political views and social behavior. Civil society is needed for, building a democratic, social and national life, civil society is a social system that grows based on the principles of civilization, justice, egalitarianism, and democracy and guarantees individual freedom and stability in society [13].

\section{Research Methods}

The research method used in this research was constructivist grounded theory. The constructivist grounded theory according to Charmaz lies right in the interpretive approach in qualitative research with flexible guidelines, focusing on developed theories that depend on the view of researchers, who learn about experiences in networks, situations, and relationships that are embedded and hidden and show a hierarchy of power, communication, and chance. Charmaz places greater emphasis on the views of values, beliefs, feelings, assumptions, and ideologies of individuals than research methods. Charmaz supports a social constructivist perspective that includes an emphasis on diverse local worlds, diverse realities, and complexities of particular worlds, views, and actions [14].

\section{Result And Discussion}

Tat Twam Asi [10], is moral teaching that breathes Hinduism. The real form can be seen from the daily lives of people, as well as everyday behavior from it. Tat Twam Asi, means that I was you. In connection with human to the human relationship can be translated "you are me" and all creatures are equal. The concept contained in this philosophy is how to become a mirror of every individual behavior. When hurting others, then their self also deplorable. Thus this lesson became the basis for behaving [15]. The traditional social life across the country, including the traditional structures, already have local wisdom in the intelligence, wisdom, cleverness forward-looking inherited from the past still exist and have the potential to organize a life in the society [16]

The teachings [17] of Tat Twam Asi rises empathy and altruism of what is felt or received by others, humans must have a sense of unity to be able to enjoy and interpret the relation of human fellows, this way of living is conveyed in the teachings of Tat Twam Asi. Tat Twam Asi [18], which means "You are Me" and in the other words "I am You" carry out the meanings or principles of grief, paro salulung sabayantara, nurture, mutual compassion and hone each other, the philosophy of this relationship is guiding us to empathize with people around us and what they are feeling. This teaching teaches humans to love other creatures, if we know how painful it is to be hurt, then so do the others, thus we must not hurt others if we do not want to be hurt by others. 
Application [18], of the teachings of Tat Twam Asi is more interpreted as a way of life that prioritizes togetherness on the basis of the interrelated fate and responsibility of humanity, so social morality is sincerely built in all aspects of life. Thus, in the context of substantial social moral responsibility, the teachings of Tat Twam Asi emerge an idea of solving social problems based on shared interests in aspects namely freedom in economic and social terms. The main points of the teachings of Tat Twam Asi are as follows [18]:

a. Interdependence among humans

b. Respect for differences

c. A feeling of communal ownership

d. Shared social responsibility

Tat Twam Asi, is essential, teaching to equalize humans before their Lord. God indeed created all human beings to the same degree and value. No one can claim that he has a higher position than others. All humans are equal, that is God's will. As a big family in the world, humans really need to live in mutual respect and mutual respect. Do not ever think that just because some people were born in nobility, they want to only be respected. Because other people want to get the same respect. Nature is always reciprocal if we want to be respected, then we must respect others. Without the same respect others get from us, it is impossible for others to respect us [10].

Human dignity [19], always must be respected, a human should never be manipulated. Human dignity implies that humans must be respected as humans, even in positions in society, heredity, or so on is the last reason I respect a human being because firstly is his dignity as a human being. This was also conveyed by the western philosopher Immanuel Kant [19], let humans always treat themselves as purposes of themselves and never just as mere means. Human dignity concerns my obligations to others. And that is the most needed, important aspect among others, carrying that human dignity can be operated in human rights.

The concept of an egalitarian society is almost similar to what is called 'civil society' by the Indonesian people because there is an egalitarian characteristic trait in civil society. Egalitarian (attitude about equality/equality between human social relations) is a characteristic trait that has become a part of the concept of civil society. Without this egalitarian nature which accommodates the formation of an ideal society, it is impossible for the concept of an equal and just society to be created. A socially just society must be preceded by the recognition of equality and equivalence in social relations so that what is called 'the ideal social order in the community' can be formed naturally and sustainably. Civil society [20], is the translation concept of the term civil society which was first rolled out or used by Dato Seri Anwar Ibrahim in his lecture at the National Symposium at the Scientific Forum at the Istiqlal Festival, 26 September 1995 in Jakarta, more clearly Anwar Ibrahim mentioned that he intended to explain that civil society is a fruitful social system that is based on moral principles that guarantee a balance between individual (individual) freedom and the stability of society. Civil society has been describing as including a broad variety of organizations such as religious groups, cultural organizations, activist and social movement organizations, professional organizations, universities, unions, media, international donor organizations, nongovernmental organizations (NGOs), and even sports teams and little leagues. Civil society is often considered an element of nation-building, wherein international and local actors seek to build democratic principles by creating a stable interpersonal and intergroup relationship based on trust [21]. Democracy is highly pertinent to civil society, a strong is usually a promotion for democratic. Civil society is also an important force to solidify and deepen democracy [22] 
An egalitarian society (civil society) work together to build social bonds, productive networks, and non-governmental social solidarity to achieve the common good [23]. The concept [24], civil society can also be literally understood as a civilized, cultured or bertamadun (politeness) society. Civil society also refers to a quality life. Civility (politeness) requires tolerance, which is the availability of individuals to accept various kinds of social attitudes or different political views [24]. Thomas Meyer also explained that [25] egalitarianism is one aspect of civil society, egalitarianism is the nature of a person who, among others, is shown through their behavior or beliefs about equal rights, achieving equal welfare and opportunities for each individual.

Departing from the values of local wisdom Tat Twam Asi as an effort to realize a more egalitarian society in all aspects of social life, it is not unlikely to be manifested through life behavior and social interaction in the community. The statement on respect for the equality of human dignity is both stated in the general statement of the United Nations Human Rights (United Nations) and in the Constitution of the Republic of Indonesia. Some important statements in respect of Human Rights are, Humans, are born free and with the same dignity, Rights to life, independence and security, Equal degree in law and protection, Rights to security, Rights to freedom of religion and politics, Rights to justice and thought, and others [10].

As a concept of the life system of civil society, it is certainly not an easy thing to achieve. Some requirements are needed so that the idea of an adequate society can be implemented well, some of the requirements are as mentioned as follows [26]:

1. The same understanding

At the initial level, it is necessary to have a general understanding among the community, about what and how the characteristics of the society are called civil society. At the very least, the basic principles concept of civil society must be understood together, so that relatively no one else does not understand what is outlined in the basic principles of civil society.

2. Belief and Mutual Trust

Fostering the belief in the community that civil society is the best community choice in realizing a social system that has been long aspired, it needs to be conditioned. Only with this belief can the process of moving towards civil society be carried out. Along with that, mutual trust must be developed among people.

3. One hearted and interdependent

By building mutual trust among the people, the next stage is needed to create the onehearted feel in determining the direction of life. The reflection and condition of one heart will be reflected from the strengthening of the sense of interdependence between individuals and groups in society.

4. Similarities to Views on Objectives and Mission

If the condition of one-hearted feel in the community has shown encouraging seeds, the similarity to views on both objectives and missions becomes easier to achieve. The differences in society certainly cannot just be abandoned, but the difference is not to be directed into something that is Uniformity or sameness but in the form of Unity and Oneness.

Foster and support the process of establishing a civil society, a high level of confidence in society is needed. And this requires the need to deconstruct feudal culture into a more egalitarian culture in the order of our people's lives. Because in that egalitarian culture, the mentality of citizens will be trained to be able to respect others. Only with respect for others, 
the self-confidence of each person will be able to grow, without feeling any interference and cultural-psychological distress, as in feudal culture [3].

An ideal community structure or community group can be achieved if there is trust in the community around the community itself. Trust is obtained by individuals and society from a social attitude that accommodates shared interests. The public general interest (social collectivism) which precedes personal or group interests is a reflection of the nature of society which has social solidity as well as social loyalty between the community and the public general interest as a shared project. In loyalty and social solidity, there is an attitude of equality, and the exclusion of social egos to achieve social harmony and social cohesion among the people. The author tries to formulate the main idea with a knife analysis approach to the constructivist grounded theory, that the value of Tat Twam Asi local wisdom begins the formation of a harmonious, solid society, mutual tolerance, and social intelligence collectivity.

This is a condition for the formation of a society that is civilized, virtuous, and social substance qualified. It is not impossible if the concept of civil society (which is egalitarian) in accordance with the elements of community formation that has been mentioned above can be realized if within that society has a solid social cohesiveness in order to build a new civilized civilization. Thus, the building of this theory can become a new understanding of the values of local wisdom that exist in the community. Not only theoretical but also applied in social life in society [27].

\section{Conclusion}

The teaching of Tat Twam Asi is more interpreted as a way of life that prioritizes togetherness on the basis of the interrelated fate and responsibility of humanity, thus social morality is truly built-in all aspects of life. Thus, in the context of substantial social moral responsibility, the teachings of Tat Twam Asi emerge an idea of solving social problems based on shared interests in aspects namely freedom in economic and social terms.

Public general interest (of togetherness) precedes personal and group interests is a reflection of the community that has social solidity as well as social loyalty between the community and the public general interest as an interest of togetherness. In loyalty and social solidity, there is an attitude of equality, and the exclusion of social egos to achieve social harmony and social cohesion among the people. Thus, the relationship between Tat Twam Asi local wisdom values as an effort to create a more egalitarian community structure is achieved through the application and implementation of ideas from Tat Twam Asi local wisdom values. The application of Tat Twam Asi local wisdom values would result in a harmonious arranged society and community systems that are full of tolerance, acknowledgment, and respect for differences, recognition of equality and equality in social relations and social stability based on the freedom of individuals responsible for each individual social attitude.

The high moral value of Tat Twam Asi should be the focus of public attention in social behavior and social interaction. So that the harmonious social ideals of society are not just some empty ideal goals, in the midst of an atmosphere of social life that is prone to friction between community groups and the individual community itself. Thereby the realization of a more egalitarian society could be realized by the application and embodiment of Tat Twam Asi values in a serious, continuous and consistent manner. 


\section{References}

[1] Huntington Samuel P, Benturan Antar Peradaban dan Masa Depan Politik Dunia. Yogyakarta: LP3ES, 2003.

[2] A. Kustin, "Survei LIPI: Isu Sara Berpotensi Hambat Pemilu 2019.," cnn indonesia, Jakarta, Aug-2018.

[3] S. Haryanto, "Konflik Sosial di Era Reformasi," J. Masyarakat, Kebudayaan, dan Polit., vol. 25, no. 4, 2012.

[4] L. Yudi, Wawasan Pancasila : Bintang Penuntun untuk Pembudayaan. Jakarta: Mizan, 2018.

[5] M. Yamin and - Wahyu, "Repositioning The Local Wisdom towards The National Curriculum," vol. 174, no. Ice 2017, 2017.

[6] S. Ambarwangi, "Reog As Means of Students' Appreciation and Creation in Arts and Culture Based on the Local Wisdom," Harmon. J. Arts Res. Educ., vol. 14, no. 1, 2014.

[7] U. Fajarini, "Peranan Kearifan Lokal Dalam Pendidikan Karakter," SOSIO Didakt. Soc. Sci. Educ. J., vol. 1, no. 2, 2014.

[8] E. Ningrum, "Learning Model Based on Local Wisdom to Embed the Ethics Land for Students," 1st UPI Int. Conf. Sociol. Educ. 2015, 2015.

[9] C. Geertz, Local Knowledge. Basic Book Inc. USA, 1983.

[10] S. Komang, Tat Twam Asi: Ajaran Kesamaan Martabat. Surabaya: Paramita, 2010.

[11] M. Kadek, "Implementation of Local Wisdom- Based Character Education in Teaching Balinese to Achieve The Vision of National Integration and The Social Harmony of Nation," in Dharma Acarya Faculty International Seminar (DAFIS) 2016, 2016.

[12] X. Fonseca, S. Lukosch, and F. Brazier, "Social cohesion revisited: a new definition and how to characterize it," Innovation, vol. 32, no. 2, 2019.

[13] F. Nur, "Konsep Civil Society Nurcholis Madjid dan Relevansinya dengan Kondisi Masyarakat Indonesia Kontemporer," J. Al-Lubb, vol. 2, no. 1, 2017.

[14] Creswell John W, Penelitian Kualitatif dan Desain Riset: Memilih diantara Lima Pendekatan. Yogyakarta: Pustaka Pelajar, 2018.

[15] W. Evitasari, "A Study Of Indigeneous Psychology: Contribution Of TAT TWAM ASI (BALINESE LOCAL WISDOM) To Construct Balinese Self -Esteem," 2nd South East Asia Psychol. Conf., no. September 2012, 2012.

[16] I. P. Gelgel, "Revitalization and Transformation of Balinese Society Local Wisdom in the Legal Development," Int. Res. J. Manag. IT Soc. Sci., vol. 4, no. 2, 2017.

[17] I. G. W. K. L. Arya, "Implementasi Ajaran Tat Twam Asi Terhadap Mahasiswa Penyandang Tuna Netra di IHDN Denpasar," J. Penelit. Agama Hindu, vol. 2, no. 2, 2018.

[18] M. K. Adhi, "Tat Twam Asi: Adaptasi Nilai Kearifan Lokal Dalam Pengentasan Kemiskinan Kultural," Semin. Nas. Ris. Inov. ke-4 2016, 2016.

[19] Bertens Kees, Etika. Jakarta: Gramedia Pustaka Utama, 2002.

[20] U. A. Rosyada Dede, Pendidikan Kewargaan (Civic Education): Demokrasi, Hak Asasi Manusia \& Masyarakat Madani. Jakarta: Prenada Media, 2003.

[21] E. J. Sommerfeldt, "The civility of social capital: Public relations in the public sphere, civil society, and democracy," Public Relat. Rev., vol. 39, no. 4, 2013.

[22] S. R. Pan, "Changing Civil Society and National Identity after the Sunflower Movement," Procedia - Soc. Behav. Sci., vol. 202, no. December 2014, 2014.

[23] Gustina, "Membangun Masyarakat Belajar Berbasis Kearifan Lokal Dalam Rangka Mewujudkan Masyarakat Madani," PROCEEDING IAIN Batusangkar, vol. 1, no. 1, 2017.

[24] A. Azyumardi, Menuju Masyarakat Madani: Gagasan, Fakta, dan Tantangan. Bandung: Remaja Rosdakarya, 2004.

[25] Tristaningrat, "Gagasan egalitarianisme dalam permainan," J. Agama Hindu, vol. 21, no. 1, 2018.

[26] Abdullah Taufik, Sairin Sjafarin, Membangun Masyarakat Madani: Menuju Indonesia Baru Millennium ke- 3. Yogyakarta: Aditya Media, 1999.

[27] K. Saddhono, "Integrating culture in Indonesian language learning for foreign speakers at Indonesian universities," J. Lang. Lit., vol. 6, no. 2, 2015. 
